\title{
Jazyková výbava Kryštofa Haranta z Polžic a Bezdružic: případ řečtiny
}

\author{
Markéta Melounová \\ (Masaryk University, Brno)
}

\section{Linguistic Competencies of Christopher Harant of Polžice and Bezdružice: the Case of Greek}

\begin{abstract}
Christopher Harant of Polžice and Bezdružice (1564-1621), an educated renaissance nobleman, is primarily known for his unfortunate fate, as he was one of the twenty-seven Czech noblemen executed at the command of the Habsburg Emperor Ferdinand II at the Old Town Square, Prague, on the 21st June 1621 for high treason. It was an ironic end of his rich and active life, for he had been loyal to the House of Habsburg for most of his life. He had served the Emperor Rudolph II for many years but after his death he stepped aside and, after the Bohemian Revolt had broken out, accepted offices from the hands of the rebel Estates, which proved fatal for him. He is equally known as the author of the elaborated and extensive, two-volume travelogue describing his journey to the Holy Land and Egypt, which he undertook in 1598 (the book was printed in 1608).

The aim of this paper was to examine the evidence that could support the thesis of the author of Harant's most recent and most comprehensive biography, Marie Koldinská, that during his long formative stay at the court of Ferdinand II, Archduke of Further Austria, at Ambras Christopher Harant learned not only Latin (which was a standard for an aristocrat of his time), but also Greek. The said evidence is formed by a few pieces of text written in Greek and a large number of references to Greek writers, both ancient and Byzantine, in Harant's travelogue.

We cannot determine the exact level of Harant's knowledge of Greek or how and when he achieved it (at Ambras? through self-study?). There were materials for learning Greek in the library of the Archduke Ferdinand at Ambras but we do not know whether Greek was actually taught here (not even in the case of the Archduke and his sons, let alone one of the pages, which was Harant). The analysis of the evidence present in the travelogue proves that Harant was capable of working with Greek texts at least at basic level. It also shows that he was familiar with a high number of various Greek authors and works but that he preferred Latin translations or bilingual Greek-Latin editions or eventually, that he sometimes helped himself with collections of proverbs and quotes or other kind of contemporary compilations. At the time when the travelogue was being created, all the Greek works quoted by Harant were already available
\end{abstract}


in Latin translations (possibly with two exceptions but the way they are quoted suggests Harant probably did not work with them directly).

\title{
Keywords
}

Christopher Harant of Polžice and Bezdružice; old Bohemian travelogue; Greek literature; quotations; Ferdinand II, Archduke of Further Austria; Ambras Castle

\begin{abstract}
Osobu Kryštofa Haranta z Polžic a Bezdružic (1564-1621) není pro českého, potažmo slovenského čtenáře třeba podrobně představovat. Vzdělaný renesanční šlechtic byl dlouhodobě věrný habsburskému domu, několik let působil na dvoře císaře Rudolfa II., po jeho smrti se však dostal do ústraní a během stavovské vzpoury pak dokonce přijal funkce z pověření stavů, což se mu stalo osudným. Paradoxně tak skončil svůj činorodý život vedle předních představitelů vzpoury na staroměstském popravišti 21 . června 1621 .

Marie Koldinská v Harantově zatím nejaktuálnější a nejpodrobnější biografii konstatuje, že jedním z jazyků, jejichž (dobrou) znalost získal díky osmiletému pobytu na dvoře arciknížete Ferdinanda II. Tyrolského na zámku Ambras (v letech 1576-1584), byla kromě pro šlechtice nezbytné latiny i řečtina. ${ }^{1} \mathrm{Na}$ jistou znalost řečtiny se dá bezesporu usuzovat po přečtení Harantova rozsáhlého učeného cestopisu, v němž popsal svou cestu do Svaté země a Egypta, podniknutou r. 1598 (tiskem ve dvou dílech r. 1608). V cestopisu se mezi množstvím citovaných autorit starověkých, středověkých i soudobých objevují v hojné míře odkazy na řecky psaná díla a také několik řeckých slov a textů. Na základě údajů, které máme o Harantově životě, však nemůžeme říci, jak to přesně s jeho vzděláním v klasických jazycích bylo; za pomoci analýzy řeckých úryvků a odkazů na řecká díla v jeho cestopisu nicméně můžeme s poměrně vysokou mírou pravděpodobnosti určit, jestli Harant pracoval $\mathrm{s}$ řeckými díly v originálu a jestli mu tudíž řečtina byla stejně blízká jako latina.
\end{abstract}

\section{Řecké autority v kontextu Harantova způsobu práce s prameny}

Kryštof Harant odkazuje celkem na 78 řecky píšících autorů starověkých i byzantských, jimiž se před čtenářem zaštituje jako autoritami a s jejichž díly tedy údajně pracoval. Potíž s určením, byl-li schopen četby v řeckém originálu, spočívá ve dvou aspektech Harantovy práce s prameny.

Zaprvé, to, že cituje dané autory, nemusí znamenat, že jejich díla měl skutečně v rukou. Odkaz mohl převzít od jiného autora, citát mohl vybrat ze sbírky sentencí anebo se mohlo jednat o všeobecnou znalost. Při dohledávání Harantových bibliografických odkazů obecně se ukazuje, že jde mnohdy o citace převzaté od jiných autorů, a to dokonce někdy i v případech, že je uveden poměrně přesný bibliografický údaj. ${ }^{2}$

1 Koldinská (2004: s. 42): „Kryštof Harant ovládal po osmiletém pobytu u arciknížecího dvora na velmi dobré úrovni němčinu, italštinu, latinu a řečtinu. Do tajů dalších jazyků (např́iklad francouzštiny) pronikl alespoň pasivně.“

2 Melounová (2017). 
Zadruhé, ani primární odkaz nedokazuje, že dané dílo muselo být čteno v originálu. Kryštof Harant mohl používat existující latinský (v některých případech i vernakulární) překlad, bilingvní vydání řecko-latinské, popř. se nabízela (latinsky) komentovaná vydání.

Pro variantu využívání latinských překladů a bilingvních vydání svědčí zejména uvádění latinizovaných jmen autorů, názvů děl a jejich zkratek ${ }^{3}$ (Harant inklinuje k přesnému uvádění titulů, jak je našel v konkrétních spisech), dále citáty z řeckých autorů v latině a minimum řeckých textů / slov v cestopisu.

Co se týče možnosti využívání latinských překladů, analýza odkazů na řecky psaná díla v cestopisu ukázala, že se mezi nimi až na dvě výjimky ${ }^{4}$ nenachází žádné, které by na přelomu 16. a 17. století neexistovalo v latinském popř. i vernakulárním překladu. Ostatně většina řeckých autorů, považovaných za hodné překladu (hodné proto, že se o nich zmiňují latinští klasici), byla díky práci humanistů přeložená do latiny už k roku 1500. V raně novověké společnosti byl obecně mnohem větší zájem o latinský překlad než o originály, což dosvědčuje fakt, že množství řeckých děl bylo vydáno nejdříve v latinském překladu a teprve poté následovalo vydání edice originálního textu (někdy i se značným časovým odstupem), což se týkalo nejen autorů pohanské antiky, ale i církevních Otců. ${ }^{5}$

\section{Korpus řecky píšících autorit v cestopisu}

Představme si nejprve jednotlivé kategorie a autory řecky psaných děl citovaných v cestopisu se zřetelem k tomu, s jakou mírou jistoty můžeme tvrdit, že s nimi Harant přímo pracoval.

Vzhledem k množství a přesnosti odkazů i uváděných informací stojí na prvním místě židovský historik Iosephus Flavius (37/8-po r. 100), z jehož děl Kryštof Harant cituje

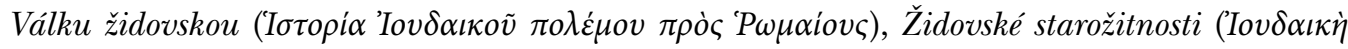

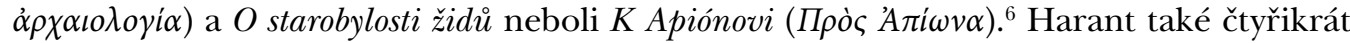
odkazuje specificky na latinské převyprávění Války od tzv. Hegesippa, zřejmě jej tedy používal vedle jiného latinského překladu Židovské války.

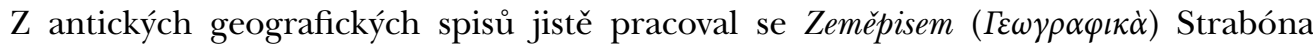

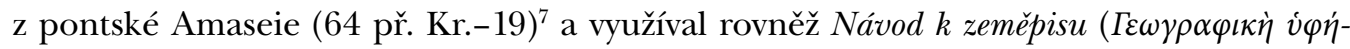
$\eta \sigma \iota \varsigma)$ Klaudia Ptolemaia (2. st.). ${ }^{8}$

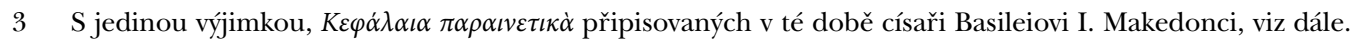

4 Dílo Anny Komnény a Níkéfora Bryennia; forma Harantova odkazu ale neimplikuje, že z jejich děl bezprostředně čerpal, viz dále.

5 Botley (2004: s. 166-167).

6 Celkem 103 bibliografických odkazů. Citováno respektive jako „bell.“, „,bello“, „de bello“; „ant.“, „anti.“, „antiq.“, „antiqui.“, „antiquit.“, „antiquitat.“, „antiquitatum“; „contra Appio.“, „contra Appionem“.

723 odkazů („Strabo“, „Strabo geogr.“, „Strabo geograph.“ apod.), z toho 3 s uvedením jména autora, názvu díla a čísla knihy a 11 se jménem autora a číslem knihy; 1 citát bez označení původu (přísloví Cretensis mare nescit; Harant /2017: 1. d., s. 112/) pocházející ze Str. 10,4,17.

87 odkazů („Ptolom.“, „Ptolomaeus“), z toho dvakrát se jménem autora a číslem knihy (jednou číslo knihy i kapitoly). 
Často citovanými autory, jež Harant znal zajisté z vlastní četby, jsou dále řecký historik

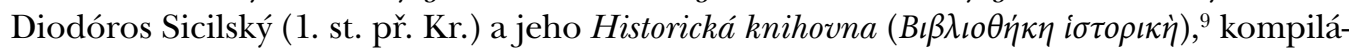
tor Athénaios z Naukratidy (2.-3. st.) a jeho Hodujici sofisté ( $\Delta \varepsilon \iota \pi v o \sigma o \varphi ı \sigma \tau \alpha i ́) .{ }^{10}$

Prostřednictvím Diodóra, ač to nepřiznává, Harant poznal řadu řeckých historiků a filozofů, jejichž díla se vůbec nebo téměř nedochovala a jež Harant beze všeho řadí mezi své autority: z Diodórových pasáží o řece Nilu opsal odkazy na filozofy Anaxagoru z Klazomen (1. pol. 5. st. př. Kr.), Thaléta z Mílétu (1. pol. 6. st. př. Kr.) a Démokrita z Abdér (asi 460-asi 370 př. Kr.), historiky Kadma z Mílétu (snad po pol. 6. st. př. Kr.), Hekataia z Mílétu (kol. 500 př. Kr.), Helláníka z Lesbu (5. st. př. Kr.), Efora z Kýmy (4. st. př. Kr.) $)^{11}$ a Theopompa z Chiu (4. st. př. Kr.), taktéž tragika Eurípida (480-407/6 př. Kr.). ${ }^{12}$

Z pojednání Girolama Fracastora (asi 1476/8-1553) o stoupání hladiny Nilu převzal odkaz na (nedochovanou) zprávu mořeplavce Euthymena z Massalie (asi 6.-5. st. př. Kr.), na nějž jednou odkazuje (v souladu s Fracastorem) jako na „Eudemena“, o něco dále ovšem přesněji jako „Euthimena“. ${ }^{13}$

Důvodně předpokládám, že citáty s odkazy na řečníky Aischina (asi 389-314 př. Kr.), ${ }^{14}$ Ísokrata (436-338 př. Kr.), satirika a filozofa Lúkiána ze Samosat (asi 120-180), autory nové attické komedie Filémóna (4./3. st. př. Kr.), ${ }^{15}$ Dífila (2. pol. 4. st. př. Kr. $)^{16}$ a Menandra (342/1-291/90 př. Kr. $)^{17}$ jsou převzaty rovněž zprostředkovaně skrze neuvedená díla, resp. svody citátů. ${ }^{18}$

Kryštof Harant nejspíš naopak měl k dispozici latinský překlad démosthenovského korpusu. ${ }^{19}$

Z děl církevního historika Eusebia z palestinské Kaisareie (asi 260-340) ${ }^{20}$ Kryštof Ha-

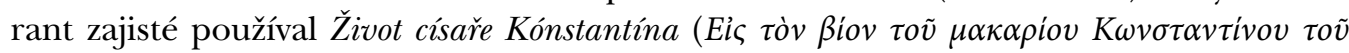

920 odkazů („Diod.“, „Diodo. Sic.“, „Diodor. Sic.“, „Diodorus“, „Diodorus Siculus“), z toho dvakrát uvedeno jméno autora a číslo knihy (jednou i dílo: hist.), jedenáctkrát autor, číslo knihy a číslo kapitoly, jednou jméno autora a asi označení díla („Diodorus hist.“).

109 odkazů („Athe.“, „Athaen.“/!/, „Athen.“, „Athenae.“, „Athenaeus“), dva jen se jménem autora, jeden s číslem knihy, zbylé i s číslem kapitoly; 1 citát bez označení původu („aurea Alexandria, Antiochia pulchra, Nicomedia speciosa“; Harant /2017: 2. d., s. 249/) pocházející z Ath. 1,36Kaibel.

11 Na Efora Harant odkazuje ještě v 1. dílu na s. 113 („Ephorus lib. de rebuspub. Europae“), kde odkaz převzal

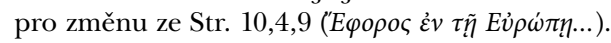

12 Harant (2017: 2. d., s. 227, 230): „Ephorus, Hellanicus, Cadmus, Hecataeus, Theopompus“; „Thales“; „Anaxagoras physicus, Euripides“; „Democritus Abderita“. D.S. 1,37,3-4 a 1,39,1.

13 Harant (2017: 2. d., s. 230). Odkazy na uvedené filozofy, historiky, Eurípida i Euthymena obsahují jen jejich jména.

14 Harant (2017: 1. d., s. 317; „Aeschines“), česká parafráze výroku.

15 Všichni tři Harant (2017: 2. d., s. 10; „Isocrates“, „Lucianus“, „Philemon“), latinské citáty.

16 Harant (2017: 2. d., s. 30), latinský citát.

17 Harant (2017: 2. d., s. 9; „Menander“), latinský citát přisuzovaný Menadrovi i Eurípidovi; a Harant (2017: 2. d., s. 121), latinský citát.

18 Pouze u Dífila to Harant přiznává: „Diphilus apud Gregorium Giraldum“; v Harantově rejstř́ku autorit, Harant (2017: 2. d., s. 378), pak uveden pouze Gregorio Giraldi (1479-1552).

192 odkazy i s čísly řečí, s latinskými citáty (démosthenovská prooimia, Třeti reč olynthská), oba (téměř) přesné („Demosth. in 17. proe.“, „Demosthenes Olynth. 3.“), Harant (2017: 2. d., s. 8, 9).

2013 odkazů („Euseb.“, „Eusebi.“, „Eusebius“). 


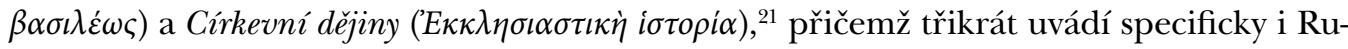
finův latinský překlad a pokračování ${ }^{22}$ dvakrát (resp. třikrát, počítáme-li odkaz bez uve-

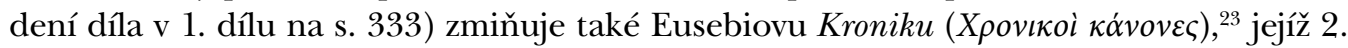
kniha je dochována díky Jeronýmovu latinskému zpracování.

Z církevních kronikářů Harant hojně a přesně odkazuje na Církevni dějiny byzantského historika Níkéfora Kallista Xanthopúla (asi 1256-1335). ${ }^{24}$ Pracoval také s Církevnimi dějinami dalších autorů: dějinami Salamana Hermeia Sózomena (1. pol. 5. st.), ${ }^{25}$ Sókrata Scholastika (kol. 380-po 439), ${ }^{26}$ Euagria Scholastika (kol. 537-po 594) ${ }^{27}$ a Theodóréta z Kyrrhoi (asi 393-asi 466). ${ }^{28}$ Uvedené dějiny byly spolu s Eusebiovými dějinami i životem Constantinovým od 2. pol. 16. st. k dispozici v latinském překladu v souborném vydání, ${ }^{29}$ ačkoliv je samozřejmě otázkou, jestli byl tento soubor dostupný Kryštofu Harantovi, v knihovně arcivévody Ferdinanda se například nenacházel.

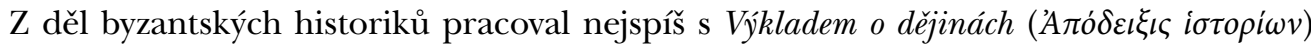

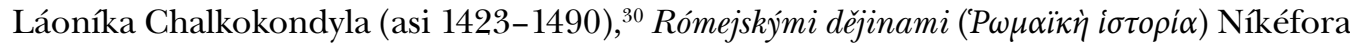

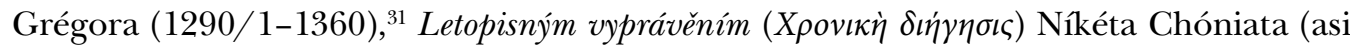

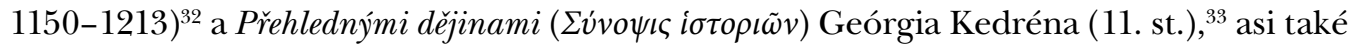

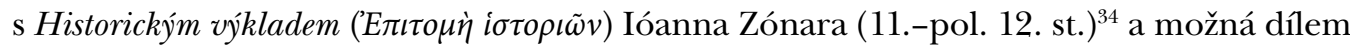

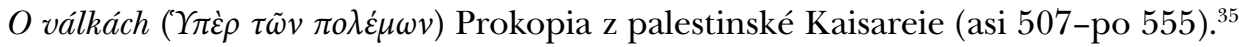

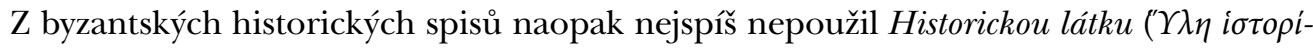

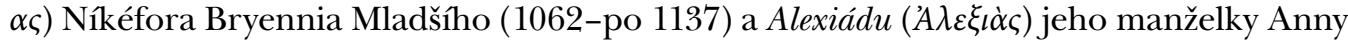
Komnény (1083-po 1148). ${ }^{36}$

21 „In vita Const.“, „in vita Constant.“; „hist. eccl.“, „hist. eccles.“, „ecc. hist.“

22 Harant (2017: 1. d., s. 184, 423), Harant (2017: 2. d., s. 300).

23 „In chron.“

2428 odkazů („Niceph.“, „Nicephorus“; je-li jmenováno dílo, pak jako „hist.“, „hist. eccl.“, „eccl. hist.“, „eccle. hist.").

258 odkazů („Sozom.“, „Sozomenus“; je-li jmenováno dílo, pak jako „hist. eccl.“, „hist. eccles.“).

265 odkazů („Soc.“, „Socr.“, „Socrat.“, „Socratem“; jednou uvedena i „hist. eccles.“).

274 odkazy („Euag.“, „Euagr.“, „Euagrius“; jednou místo čísla knihy a kapitoly uveden jen název kapitoly, „,de Palest. monachis").

283 odkazy („Theod.“, „Theodor.“; jednou uvedena i „,hist. eccles.“).

29 Historiae ecclesiasticae scriptores Graeci, 1. vydání Lovaň 1569; Binns (1978: s. 133).

303 odkazy („Laonicus“, „Chalcocondylas“; dílo značeno jako „de rebus Turcicis“ a „hist.“), jeden na konkrétní knihu (ale bez názvu díla, Harant /2017: 2. d., s. 299/: „Chalcocondylas lib. 3.“).

311 odkaz na konkrétní knihu, Harant (2017: 2. d., s. 84): „Niceph. Gregoras hist. Rom. lib. 2.“

322 odkazy („Nicetas“), jeden na konkrétní knihu, Harant (2017: 2. d., s. 84): „Nicetas chroni. lib. 2. de reb. Manuelis imp."

332 odkazy („Cedrenus“, „Cedren. in chron.“), první spolu s parafrází.

344 odkazy („Zonaras“, „Zonoras“/!/), 2 s číslem svazku („tom.“).

352 obecné odkazy, bez názvu díla („Procopius“).

36 Obojí 1 odkaz. Latinské překlady nalezeny až k roku 1661 v případě Níkéfora a 1651 u Alexiády, jejíž řecký text byl poprvé edičně vydán r. 1610. Kryštof Harant na oba odkazuje pouze povšechně a uvádí jen jména autorů, což u něj většinou znamená, že cituje zprostředkovaně. U Bryennia uvádí pouze jméno Níkéforos, z kontextu lze vyvodit, že by se mělo jednat o tohoto autora (Harant všude jinde pod Níkéforem myslí 


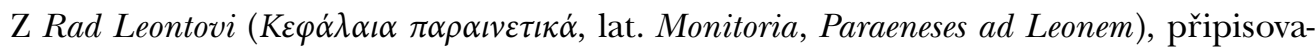
ných tehdy císaři Basileiu I. Makedonci (vládl 867-886), cituje Harant dlouhou latinskou pasáž, je tedy pravděpodobné, že je měl v ruce, a to nejspíš jako bilingvu. ${ }^{37}$

Zcela jistě byl obeznámen s dílem byzantského císaře Ióanna VI. Kantakúzéna (vládl 1341-1354) polemizujícím s učením islámu a obhajujícím křestanství (čtyři apologie a čtyři polemické řeči): jeho latinský překlad podruhé vyšel v Harantovi známém souboru spisů protestantského teologa Theodora Buchmanna (Bibliandra, 1509-1564) doplňujících Buchmannovu edici Koránu. ${ }^{38}$

Z autopsie znal snad byzantský slovník Súda ${ }^{39}$ a zřejmě i Výtah z Basilik ( $\Sigma v ́ v o \psi \iota \varsigma ~ B \alpha \sigma ı \lambda_{l}$ $\kappa \tilde{\omega} v ; 10$. st.), výtah právního souboru v 60 knihách sestaveného v 9. st. $^{40}$

Prostřednictvím díla katolického biskupa Luigiho Lippomana (Aloisius Lipomanus, 1496-1559) Vitae sanctorum priscorum Patrum nejspíš poznal životopis sv. Daniela Sloupovníka z ménologia byzantského hagiografa Symeóna Metafrasta (10. st.; svazky V-VII Lippomanova souboru obsahují životy z ménologia). ${ }^{41} \mathrm{Z}$ vlastní četby asi znal nespecifikované dílo byzantského teologa Ióanna Damaskéna (asi 675-před 749) a $L e^{42}$

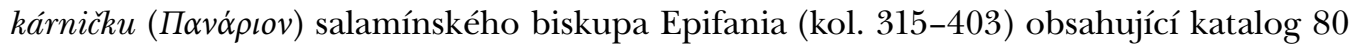

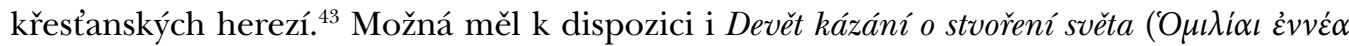

církevního historika Níkéfora Kallista): „Pod jejich pak mocí [tj. Řekové], i za časův monarchiae římské v Římě, i též monarchiae přenešené do Konstantinopole do vlasti jejich, zůstávali a byli několik set let pořád, kteříz jak spravováni od císařův byli, mnoho by se mohlo psáti. Ale vypisují to Zonaras, Procopius, Nicetas, Nicephorus, Annas Alexiados a jiní historikové.“ Harant (2017: 1. d., s. 413).

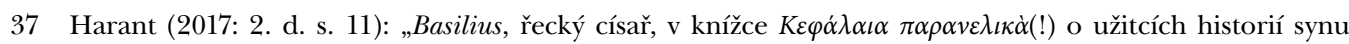
svému předkládá: Per historias ire ne recusa..."

381 odkaz, Harant (2017: 2. d., s. 309): „Pobožný čtenář může sobě o všech jeho bludích ty, kteříž o tom obšírně piší, čísti, jako předně Cantacuzenus, císař konstantinopolitánský, lib. contra fidem Mahumet." Latinský překlad Kantakúzénových spisů vyšel ve 2. svazku 2., rozšriřeného vydání Bibliandrovy edice Koránu s doplňky r. 1550.

394 odkazy („Suidas“), jednou s řeckým citátem.

$40 O D B$, s. v. Basilika a Synopsis Basilicorum. 1 odkaz s přesností na knihu a titul („Synopsis Basil. 6. tit. 35.“, správně), Harant (2017: 1. d., s. 366). Výtah je citován vedle latinského Codexu Theodosianu a i s ohledem na latinskou verzi názvu se mi zdá pravděpodobné, že Harantovi bylo k dispozici minimálně komentované vydání, ne-li př́mo latinský překlad (Leunclaviova basilejská edice doplněná latinským překladem vyšla $\mathrm{r}$. 1575). V rejstř́ku autorit, Harant (2017: 2. d., s. 395), uvedeno jako „Synop. Basilicon“.

41 Harant (2017: 2. d., s. 139), vedle sebe odkaz na Metafrasta i Lippomana jen s uvedením jmen autorů (,Metaphrastes, Aloisius Lippomanes“).

421 odkaz bez uvedení názvu díla, ale s číslem knihy, Harant (2017: 1. d., s. 193): „Židé, farizeové a jim podobná sběř, i ten jeden spolutrpící lotr na křriži všelijakým rouháním mu se posmívali, takže s velikou ovšem a nesnesitedlnou srdce bolestí toho všeho doslýchati a viděti musil. Avšak za ně se modliti ráčil, řka: ,Pater, dimitte illis, non enim sciunt, quid faciunt," totiž: ,Odpust̉ jim to, Otče, nebt̉ nevědí, co činí." Až poroučeje duši svou milou Otci svému nebeskému, v hodinu devátou, dvacátého pátého dne měsíce března, léta od narození svého třicátého třetího a třech měsícův, život svůj dokonati ráčil. Greg. Nazianz. in tragaed. Christus patiens, Hier. in Mar. c. 15., Iohan. Damasc. lib. 4., Beda in Lucae 23." Mohla by být myšlena

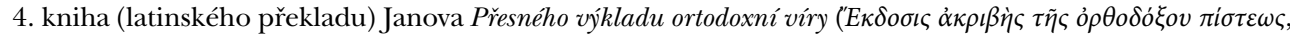
lat. De orthodoxa fide), pojednávající mj. o mystériu vzkříšení. Latinský překlad tohoto Janova díla najdeme v sebraných spisech vydaných už r. 1546.

432 odkazy („Epiphan.“, dílo uváděno jako „haeresi.“, „in cat. haeret.“), z nich jeden s číslem svazku, knihy i hereze. 
Eiৎ $\left.\tau \tilde{\eta} v^{`} E \xi \alpha \dot{\eta} \mu \varepsilon \rho o v\right)$, soubor homilií na 1. kapitolu knihy Genesis kappadockého Otce Basileia Velikého (asi 330-379), ${ }^{44}$ možná též nějaké dílo (ze souborného vydání?) Kléménta Alexandrijského (kol. 150-před 215). ${ }^{45}$

S díly Řehoře z Nazianzu (329/30-389/90) Kryštof Harant spíše nepracoval: jmeno-

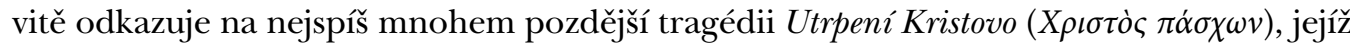
autorství se Řehořovi někdy připisovalo, ${ }^{46}$ bez specifikace na první řeč $O$ míru, ${ }^{47}$ a rovněž bez specifikace uvádí sentenci tradovanou pod Řehořovým jménem (v latině). ${ }^{48}$

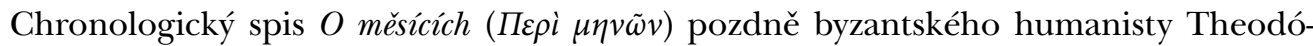
ra Gazéta (asi 1400-1476) jistě nečetl, odkaz spolu s odkazem na nesprávné dílo Bedy Ctihodného (De natura rerum namísto De temporum ratione) převzal od Matthia Beroalda (Brouarda, asi 1520-1576) z jeho chronologického pojednání. ${ }^{49}$

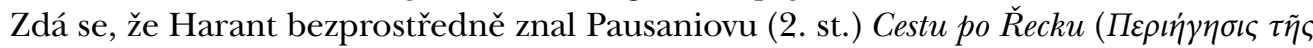
E $\lambda \lambda \alpha ́ \delta o \varsigma),{ }^{50} \mathrm{z}$ četby mohl znát didaktickou báseň Dionýsia Periégéta (1. pol. 2. st.) Cesta ko-

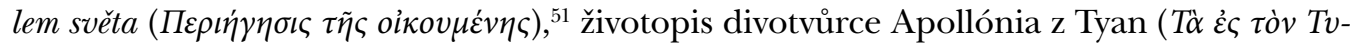

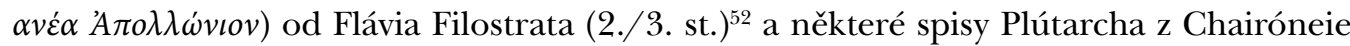

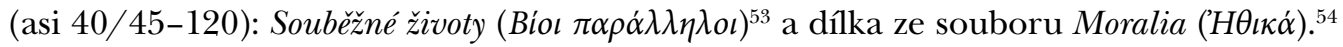

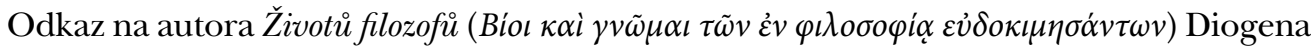
Láertia (3. st.) s číslem knihy ${ }^{55}$ ovšem naopak ukazuje, že ani takto přesné odkazy nemusí

441 odkaz s číslem kázání („Basilius in 4. hom. sex dierum“), Harant (2017: 2. d., s. 156).

451 odkaz v souvislosti s novotami zaváděnými v křestanském kultu Egyptany, Harant (2017: 2. d., s. 301), jen jméno autora („Clemens Alexand.“).

46 Harant (2017: 1. d., s. 193): „Greg. Nazianz. in tragaed.(!) Christus patiens“.

47 Harant (2017: 1. d., s. 346): „Svatý Jeroným a Nazianzenus, učitelé církevní, napsali, že každého roku na ten den, když město [tj. Jeruzalém] vyvráceno bylo, židé na to zbořené místo přicházeli a nad tou zkázou plakávali a žalostivě kvílívali...“. Myšlen Jeronýmův komentář k Sf 1,14-16 (PL 25,1354A-C) a Řehořova řeč č. 6, O miru 1, odst. 18 (PG 35,745B-C).

48 Harant (2017: 2. d., s. 10): „vedlé Gregoria Nazianzena napomenutí, praeclarum est mentem historiarum cognitione instructam habere“. V Řehořově díle nenalezeno.

49 Vyšlo r. 1575 samostatně jako Chronicum scripturae Sacrae autoritate constitutum. Harant (2017: 1. d., s. 420): „Beda de natura rerum, Theodorus Gaza de mensibus, Beroaldus lib. 4. chronic. “ Převzato z Beroaldovy Kroniky, kn. 4, kap. 2.

504 přesné odkazy („Pausanias“; dvakrát jmenuje knihu č. 8 o Arkádii / „Arcad.“/, dvakrát uvádí jen číslo knihy).

515 odkazů jen se jménem autora; v rejstříku autorit, Harant (2017: 2. d., s. 375), je specifikován jako „Dionisius poeta“ (a možná je tento Dionýsios myšlen i pod následujícím „Dionisius hist.“ - žádného Dionýsia historika totiž Harant nikde neuvádí).

522 odkazy („Philostr. in vita Apoll.“, „Philostrati de vita App.“/!/), jeden s přesností na knihu.

53 Bez uvedení názvu život Alexandrův, jmenovitě život Pompeiův, život Marka Antonia („Plutarchus“, „in Pompeio“, „in vita Antonii“).

54 Pod odkazem „Vide Plutarchum in vit. animal.“, Harant (2017: 1. d., s. 96; o delfínovi), se zřejmě skrývá

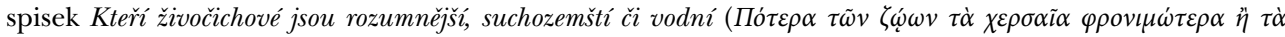
हैvv $\rho \rho \alpha$ ), stejně tak v rejstř́íku autorit, Harant (2017: 2. d., s. 392): „Plutarchus histor. vitas animalium“. 1

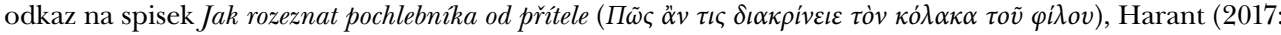

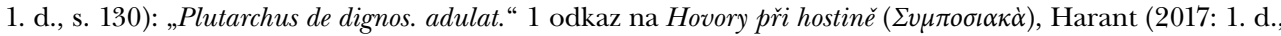

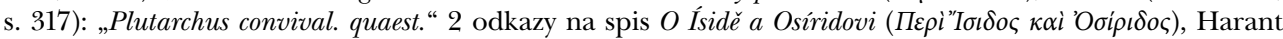
(2017: 2. d., s. 233, 300; jednou bez názvu spisu a jednou „Plutarch. de Iside“). 
být důkazem Harantovy práce s daným pramenem, nebot’ se díky podrobnému rozboru prokázalo, že odkaz na Láertia Harant mohl převzít z kompilace Geniales dies neapolského právníka a učence Alessandra d'Alessandro (Alexander ab Alexandro, 1461-1523). ${ }^{56}$

Epigramy z Řecké anthologie Harant nejspíš poznal díky existujícím latinským překladům, nebot jeden parafrázuje česky, z druhého cituje latinsky. ${ }^{57}$

Z vlastní četby znal Kryštof Harant některá díla Galéna z Pergamu (asi 129-199),

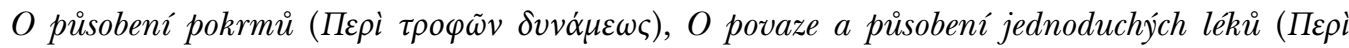
$\kappa \rho \alpha \dot{\alpha} \sigma \varepsilon \omega \varsigma \kappa \alpha i ̀ ~ \delta v v \alpha \dot{\alpha} \mu \varepsilon \omega \varsigma \tau \tilde{\omega} v \dot{\alpha} \pi \lambda \tilde{\omega} v \varphi \alpha \rho \mu \dot{\alpha} \kappa \omega v)$, a galénovské podvrhy, Liber de aquae bonitate (citováno jako dílo Galénovo) a De dynamidiis (citováno jako podvrh); uvádí i jednu informaci z Galénova komentáře k hippokratovským Epidémiím, protože na dílo ale konkrétně neodkazuje, domnívám se, že informaci převzal odjinud. ${ }^{58}$

$\mathrm{Z}$ děl filozofa a př́ŕrodovědce, Aristotelova žáka Theofrasta z Eresu (asi 372/70-288/6

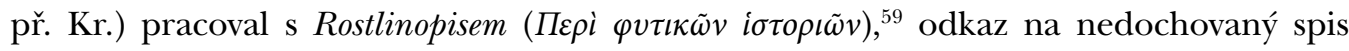

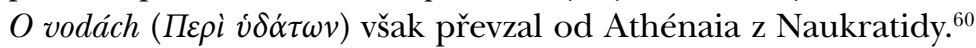

Z četby mohl znát i oblíbenou didaktickou báseň Níkandra z Kolofónu (3. nebo 2. st. př. Kr.) O lécích proti jedovatým kousnutím $(\Theta \eta \rho \iota \alpha \kappa \grave{\alpha})^{61}$ a významnou farmakologickou prá-

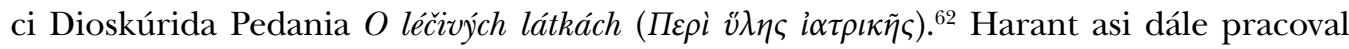
$\mathrm{s}$ řecky psanými spisy ř́mského rétora Claudia Aeliana (Klaudios Ailiános, asi 175-235)

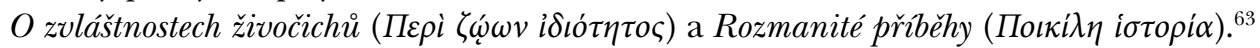

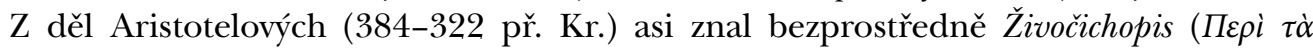

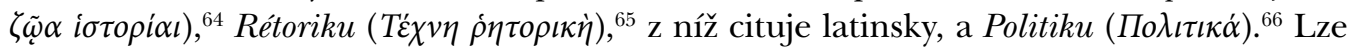

56 A navíc spletl číslo knihy, viz Melounová (2017: s. 287, 289).

57 Harant (2017: 1. d., s. 112): „Jakož toho příklad divný se čte, že jeden v Cretě orla v letu šípkou dostřelil a trefil, kterýž z vysoka prudce dolů spadši na hlavu střelce upadl a jeho týmž šípem na smrt zranil, takže tu oba umřeli. Apollonides in epigram. 1." (Anthologia Palatina 9,265, Apollónidás ze Smyrny); Harant (2017: 2. d., s. 262): ,jakž Antiphilus pokládá, fructibus contendimus, non stadiis“ (Anthologia Palatina 9,413, Antifilos z Byzantia).

58 Celkem na Galénova / galénovská („Galen.“, „Galenus“) díla 6 odkazů: 2 na Působení pokrmů („de alim. facult.“; jeden s číslem kapitoly, jeden bez uvedení díla), 1 na Jednoduché léky („,e simpl. med. facult.“, s číslem knihy a kapitoly), 1 na Knihu o kvalitě vody (,lib. de aquae bonit.“; jen název díla), 1 na Silné léky („,e dynamid. spur.“; s číslem knihy), 1 na komentár ke 3. kn. Hippokratových Epidémií, jen se jménem autora („Galenus a jiní to vysvědčuji“; o „výpůjčce“ spisů tř́ velkých attických tragiků Ptolemaiem III.), Harant (2017: 2. d., s. 256).

593 odkazy („Theofr.“/!/, „Theophrastus“), $1 \mathrm{~s}$ přesností na knihy a kapitoly, ale ani jednou nejmenováno dílo.

60 „Theophrastus lib. de aquis“, Harant (2017: 2. d., s. 52); Ath. 2,15Kaibel.

611 odkaz jen se jménem autora („Nicander“), Harant (2017: 2. d., s. 240; popis promyky ichneumona).

624 odkazy (,Diosc.“, „Dioscorides“), jednou s přesností na knihu a kapitolu, ale bez názvu díla.

633 odkazy („Aelianus“, „Elianus“), jednou s názvem díla a číslem knihy („de var. hist. lib. 2.“), Harant (2017: 2. d., s. 114), dvakrát jen jméno autora (myšleny zjevně Zvláštnosti živočichů), Harant (2017: 1. d., s. 96), Harant (2017: 2. d., s. 237).

64 Ze 4 odkazů jeden jen se jménem autora („Aristot.“), jeden s názvem díla převzatý od Strabóna (o účincích řeky Nilu, Harant /2017: 2. d., s. 52/, Str. 15,1,22), dva s přesností na knihy a kapitoly (zkratky díla: „hist. anim.“, „hist. animali.“, „animal.“).

651 odkaz, Harant (2017: 1. d., s. 18): „Aristoteles lib. 1. rhet. cap. 7.“

664 odkazy, z toho $1 \mathrm{~s}$ názvem a přesností na knihy a kapitoly, 1 s názvem (obojí „polit.“) a číslem knihy, 1 bez názvu díla (krétská pederastie, Harant /2017: 1. d., s. 113/) a jeden, kde zřejmě mísí Politiku s př́íprav- 
předpokládat, že obecný odkaz na Aristotela v souvislosti s alternativním názvem ostrova Kythéra však převzal prostřednictvím nespecifikovaného díla: údaj odvolávající se

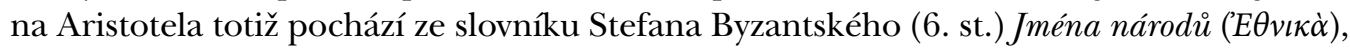
dochovaného ve výtahu, s nímž Harant spíše nepracoval, nebot na něj neodkazuje, vyloučit to ale nemůžeme. ${ }^{67}$

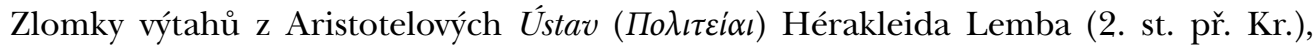
z nichž odkazuje na výtah z ústavy Etrusků a Krétanů, ${ }^{68}$ mohl znát z vlastní zkušenosti: společné vydání Hérakleidových zlomků a spisu Historia varia Claudia Aeliana, na nějž odkazuje přesně (viz výše), vyšlo poprvé v Lyonu r. 1553 a vycházelo hojně i dále (střídavě v Lyonu a Paříži), od lyonského vydání z r. 1587 jako řecko-latinská bilingva.

Kryštof Harant možná četl Platónův (428/7-348/7 př. Kr.) dialog Zákony (Nó

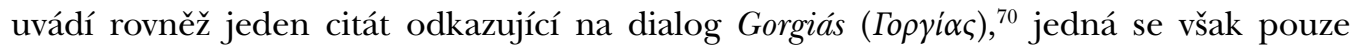
o jeden z dlouhé řady citátů a aforismů na začátku 2. dílu cestopisu, tudíž není nutné předpokládat, že dialog znal z vlastní četby.

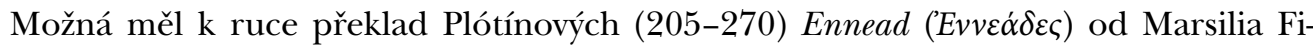
cina. ${ }^{71}$ Usuzuji na to zejména proto, že měl zřejmě $\mathrm{k}$ dispozici spisy dalších raně novověkých platóniků: na začátku cestopisu odkazuje na zdroj s označením „Mercurius Trimegistus(!)“, ${ }^{72}$ čímž zřejmě myslí Ficinův překlad čtrnácti traktátů z tzv. Corpus Hermeticum; cituje též spisy dalšího popularizátora platónismu, Giovanniho Pica della Mirandola (1463-1494), a zejména jeho synovce Giovanniho Francesca (1469-1533) ${ }^{73}$ včetně Fran-

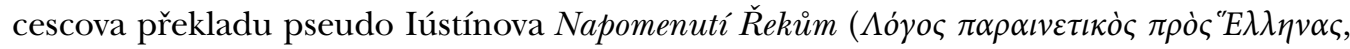
asi 4. st., lat. Admonitorius gentium). ${ }^{74}$

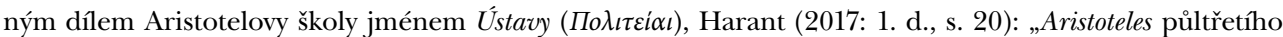
sta obcí obyčeje a práva shromáždil a do jedné knihy poznamenané vydal, kteráž však naších časův a nás nedošla“ (výše je ovšem citována právě Politika, s přesností na kapitoly). V 1. dílu na s. 17 uvádí ještě bez přesnějšího odkazu: „Aristoteles, znamenitý filozof, svědčí, že známost cizích a domácích věcí nejpodstatnější v životu obcování užitek přináší“.

67 Harant (2017: 1. d., s. 104). Informace je navíc doplněna o nepřesnost: „Aristoteles jmenuje jej Porphyris, pro lom mramoru“. Myšleno je purpurové barvivo, jehož zpracování se na ostrově předpokládá už ve 3 . tis. pr. Kr. Burke (1999: s. 80).

68 „Heraclides“; celkem 2 odkazy: „, in politia Tyrrhenorum“ (Etruskové), Harant (2017: 1. d., s. 79); „Heraclides in politicis“ (myšleni Krétané), Harant (2017: 1. d., s. 113).

693 odkazy („Plato“, „de legibus“), jednou s číslem knihy.

70 Harant (2017: 2. d., s. 9): „Ale jak Pláto těší: Melius est iniuriam accipere, quam iniuriam facere." Pl. Grg. např. $475 \mathrm{~d}$ a Cic. Tusc. 5,19,56.

711 odkaz s číslem enneady, Harant (2017: 2. d., s. 46): „Plotinus enead. 3.“

72 Harant (2017: 1. d., s. 21).

73 Přesné odkazy (s čísly kapitol) na Picovo nedokončené, posmrtně vydané pojednání Disputationes adversus astrologiam divinatricem, na Examen vanitatis doctrinae gentium a De rerum praenotione jeho synovce (bez rozlišení obou autorů). Harant (2017: 2. d., s. 150): „Pic. Mirandula lib. 1. vanit. gent. et lib. 8. c. 6. in astrolog.“, Harant (2017: 2. d., s. 158): „Pic. Mirand. lib. 1. de van. gent. c. 2. etc., lib. 7. de rer. etc. praenot. c. 9.“ Spisy Giovanniho Francesca Mirandoly se nacházely i v knihovně Ferdinanda Tyrolského na zámku Ambras (Opera 1 Theo 280 , De rerum praenotione 5 Co 128 , a navíc De auro 5Co 746), stejně tak Opera jeho strýce (1Theo 279, 1Theo 806, 5Co 496). „Signatury“ z Ferdinandovy knihovny uváděny podle Purš \& Kuchařová (2015).

74 Harant (2017: 2. d., s. 251): „svědčí to Iust. philos. et martyr admon. gentium“. 


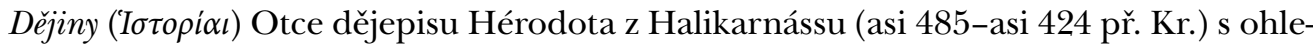
dem na množství odkazů i na jejich relativní přesnost Harant asi v ruce měl. ${ }^{75}$

Nejasná je otázka práce s Dějinami Polybia z Megalopole (asi 200-118 př. Kr.). Jeden ze čtyř odkazů je převzatý od Athénaia, ${ }^{76}$ jeden je velmi obecný ${ }^{77}$ a dva nedohledatelné, ${ }^{78}$ dílo tedy asi znal, ale přímo s ním spíše nepracoval.

Z řeckých pragmatiků dále odkazuje dvakrát na Thúkydida a jednou na Xenofonta, z děl ani jednoho z nich však asi přímo nečerpal, soudíc podle nepřesného shrnutí jejich obsahů, spíš je měl v povědomí jako součást svých všeobecných znalostí (jejich přítomnost v Harantově knihovně samozřjejmě také nelze vyloučit). ${ }^{79}$

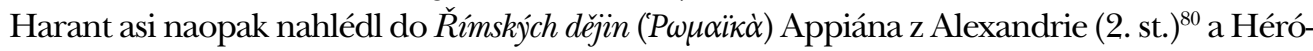

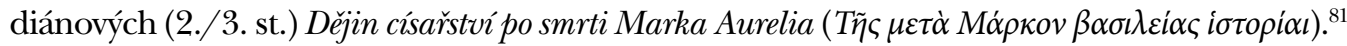

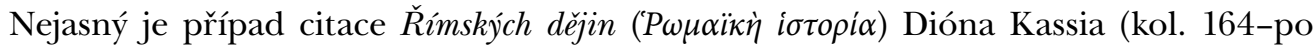
229): Dión se objevuje pouze jednou bez uvedení díla, navíc ve spojení se scestným odkazem na Iosepha Flavia, takže to vypadá, že odkaz byl odněkud převzat, anebo jde o Harantovu všeobecnou znalost. ${ }^{82}$

7521 odkazů, z nichž 8 obsahuje jméno autora („Herod.“, „Herodotus“) s číslem knihy, ovšem ne vždy jsou v pořádku. Jeden je téměř jistě převzatý od Athénaia, Harant (2017: 2. d., s. 52; zde jediný výskyt zkratky díla, „hist.“), historka o perském králi, který si s sebou bral vodu z řeky Choaspés, Harant ji napojuje na historku o nilské vodě a dceři Ptolemaia II. provdané do Sýrie, kterou převzal údajně z Polybia (viz níže), oba př́iběhy vedle sebe uvádí Ath. 2,23Kaibel. Jeden odkaz s mylným údajem: Harant (2017: 2. d., s. 156), král „Sestoris“ jako stavitel búbastského kanálu, ačkoliv Hdt. 2,158 uvádí Nekóa. Jeden odkaz spíš patř̌i k Homérově Illiadě 9,383 (egyptské Théby „100 bran mající a jiných k víře téměř nepodobných obzvláštností, o níchž Herod. a jiní písí“, Harant /2017: 2. d., s. 232/). U jednoho odkazu je nejasné, k čemu by se měl u Hérodota vztahovat, Harant (2017: 1. d., s. 114; Kréta): „V témž ostrovu bylo za starodávna do 100 hražených měst, jakž svědčí... Herodotus, Polibius(!)..." (viz níže u Polybia).

76 Harant (2017: 2. d., s. 52), Ath. 2,23Kaibel. Ptolemaios II. posílal své dceři Bereníké Fernoforos, provdané za syrského Antiocha II., vodu z Nilu, viz výše u Hérodota, také Melounová (2017: s. 290).

77 Harant (2017: 1. d., s. 413): „Po Alexandrově smrti začaly se války mezi jeho předními hejtmany a oficíry ... pročež řecká země přišla jiným v moc a mezi potomky jejich mnohé zlé snášeti musila, jakž to Polybius vypisuje."

78 Harant (2017: 1. d., s. 102): úrodnost ostrova Zakynthu přinášející blahobyt, pro nějž obyvatelé ostrova zapomínali na válečné záležitosti; Harant (2017: 1. d., s. 114): údajná zmínka o stu krétských městech, ta se jinak nachází u Homéra, Il. 2,649, viz výše u Hérodota.

79 Harant (2017: 1. d., s. 412): „Potom povstali proti nim [tj. Řekům] perští monarchové a všelijak se o ně pokoušeli... jakž o tom pěkné a hodné paměti píši Herodotus, Thucidides a jiní historikové“. Odkaz ve 2. dílu cestopisu na s. 227 („A takž jiní staří všickni divně o řece té smýšleli, až na to přišli... ji za svatou řeku měli a ctili, jako Ephorus... Theopompus, Thucidides a jini“") převzal Harant spolu s dalšími jmény řeckých historiků píśících o řece Nilu z Diodóra Sicilského (D.S. 1,37,3-4).

Xenofón: „Odkudž pošlo, že jedna obec proti druhé z př́čin špatných a různic nehodných válku domácí začaly, moho let mezi sebou se mordujíce až do zemdlení a k králi macedonskému Philippovi někteří se o pomoc utíkali... až naposledy vší řecké země správcím a ochráncím učiněn... byl, o čemž Xenophon a Diodorus Siculus dostatečně vypisuji.“ Harant (2017: 1. d., s. 412). Jak známo, Thúkydidés nepsal o řecko-perských válkách ani Xenofón o Filippovi Makedonském.

801 odkaz bez názvu díla, ale s č́slem knihy („Appian. Alexandr. lib. 5.“; 5. kniha, tj. kniha ze série o občanských válkách), Harant (2017: 1. d., s. 366).

812 odkazy („Herodia.“, „Herodianus“), 1 jen se jménem autora, 1 se jménem autora a číslem knihy.

82 Harant (2017: 1. d., s. 345): „o čemž Dion a Iosephus písíi“ (myšleno o následcích Bar Kochbova povstání v Jeruzalémě; Josef, jak známo, o této době už nepíše). 
Homérské eposy Íliadu i Odysseiu znal Harant nejspíše z vlastní četby, v případě obou odkazuje jednou (přesně) na konkrétní knihu; minimálně podle názvu znal také latinská románová vyprávění Diktya Krétského a Daréta Fryžského, která bývala v 16. století vydávána společně s homérskými eposy. ${ }^{83}$

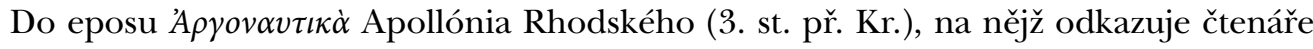
ve výkladu o původu řádu Zlatého rouna, zjevně alespoň nahlédl (zná báji o Argonautech, Iásónovi, jeho zisku rouna a Médeii) ${ }^{84}$ Snad četl nejmladší z vcelku dochovaných

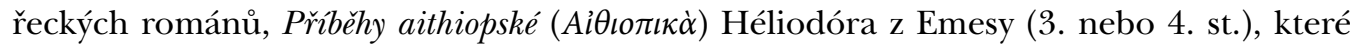
cituje s přesným údajem o knize. ${ }^{85}$

Kuriózní př́ípad přebírání citací představuje výpověd’ krétského biskupa Geórgia Alexandrú (15. st.), jehož Harant cituje, jako by šlo o primární citaci autority, ačkoliv výpověd' prokazatelně převzal z encyklopedie Raffaela Maffei (Volaterrana, 1451-1522), Commentariorum urbanorum libri XXXVIII. ${ }^{86}$

Pracoval také zjevně se souborem podvrhů Antiquitates variae viterbského Giovanniho Nanniho (Iohannes Annius Viterbiensis, 1437-1502), z nějž odkazuje na „starožitného historika“ Bérósa z Babylónie (3. st. př. Kr.) a údajné doplňky egyptského Manethóna (3. st. př. Kr.) k Bérósovi (Supplementa Manethonis ad Berosum; Nanni pochopitelně neuveden). ${ }^{87}$

\section{Řečtina na zámku Ambras u Innsbrucku}

Jak bylo řečeno v úvodu této studie, strávil Kryštof Harant dlouhých osm let (1576-1584, od 12 do 20 let svého věku) na dvoře arciknížete Ferdinanda II. Tyrolského, syna císaře Ferdinanda I. Habsburského. Zde získal jedinečnou možnost vzdělávat se po boku dalších mladých aristokratů i arcivévodových dvou synů v duševních i tělesných dovednostech potřebných pro mladé aristokraty. Kromě určitého základního vzdělání nabytého předtím ve vlasti byl tento pobyt jediným formativním obdobím Harantova života; kavalírskou cestu po Evropě, jako jiní šlechtici jeho doby, nikdy nepodnikl. ${ }^{88}$ Pokud tedy máme uvažovat o nabytí znalostí řečtiny, nemohlo se tak stát nikde jinde, jedině

83 Purš \& Kuchařová I (2015: s. 336). 2 odkazy Ílias: 1 odkaz na 2. zpěv („Homer. Iliad. 2.“) v souvislosti s výčtem řeckých krajin, jedná se tedy nejspíš o odkaz na Katalog lodí v Il. 2,494-759; 1 obecný: „Homerus Iliad., Dictys Cretensis a Dares Phrygius etc.“, že se tu píše o trójské válce, oba Harant (2017: 1. d., s. 411). 1 odkaz Odysseia: řeka Nil „potom sloula Orelice, jakž ji Homerus tak jmenuje, Aegypt. 4. Odis.“, Harant (2017: 2. d., s. 226). V seznamu autorit uveden jen „Homerus Iliad.“, Harant (2017: 2. d., s. 381).

84 Odkaz obecný: ,jakž o tom šíreji Apollonius Rhodius a Valerius Flaccus a jiní písíi“, Harant (2017: 1. d., s. 367).

85 Harant (2017: 2. d., s. 221; o uctívání řeky Nilu): „O tom o všem vysvědčují staří škrybenti Strabo lib. ult., Plin. lib. 5. c. 9., Heliod. lib. 9. Aethiopi., Giov. Lioni 8. parte etc.“.

86 Harant (2017: 1. d., s. 114): „O kterémžto [tj. labyrintu] aby každý věděl, co by byl, mezi jinými mnohými authory jednoho slova vlastní tuto položím, kterýž jej vypisuje takto: jest prý vrch z skály... Georgius Alexander, někdejší správce(!) téhož ostrovu na místě panův Benátčanův. Volaterranus a Bellonius pišsí, že by byl nápodobný skále..." U Volaterrana (9. kn., s. 345e) je Geórgios označen latinsky jako praesul.

87 „Připomíná to též jeden starožitný historik, Berosus in Ascatade..."; „Maneth. in supple. Berosi“; Harant (2017: 2. d., s. 153, 261).

88 Koldinská (2004: s. 35). 
s výjimkou samostudia, na něž mu ale vzhledem k jeho aktivnímu životu a angažovanosti u pražského císařského dvora ${ }^{89}$ asi nezbývalo př́iliš mnoho času. Není sice doloženo, že by se samotný arcivévoda nebo jeho synové učili / že by uměli řecky, řečtina k raně novověkému „aristokratickému minimu“ nepatřila,${ }^{90}$ jisté indicie ohledně řeckého vzdělávání na Ambrasu nám však poskytuje katalog arcivévodovy knihovny. Na rozdíl od Harantovy knihovny se v případě té arcivévodovy dochoval rozsáhlý pozůstalostní inventář, na jehož základě byl nedávno sestaven a publikován moderní katalog. ${ }^{91}$

Katalog jednoznačně dokazuje, že řecká studia na Ambrasu možná byla - jestli byla právě v Harantově př́ípadě i realizovaná, to už nám bohužel potvrdit nemůže. V knihovně se nacházelo poměrně dost pomůcek pro studium řečtiny a řeckou četbu: řecké jazykové př́ručky stojí svým počtem 19 položek hned na druhém místě za latinskými. Mezi gramatikami najdeme významné práce Manuéla Chrýsolóra, Alda Manutia a Philippa Melanchthona i jiné, slovníky jsou zastoupeny jak řecko-latinské, tak trilingvní italsko-latinsko-řecké nebo latinsko-řecko-hebrejský (v knihovně nechyběly ani gramatiky hebrejštiny). Kromě toho se tu vyskytovaly gramatické tabulky řečtiny („Graecae linguae tabulae“) a pomůcka k výuce alfabety („Alphabetum graecum, sine comperto“).$^{92}$

Kromě filologických prací se v knihovně podle odhadu M. Vaculínové a M. Bažila nacházelo asi 50-60 děl řecké literatury, což je poměrně malý počet vzhledem k celkovému rozsahu knihovny, z nichž navíc jen 6 mohlo být psaných pouze řecky. Jde o Nový zákon, Súdu, jedno vydání Plútarchových životopisů, Appiánovo dílo, dílo Apollónia Rhodského a básnické ztvárnění životů římských císařů od Caesara po Karla Velikého od německého, vavřínem ověnčeného básníka Zachariase Ortha (kol. 1530-1579). ${ }^{93}$ Převážná část řeckých děl se v knihovně vyskytovala ve formě latinských překladů, bilingvních řecko-latinských vydání nebo vydání s latinskými komentáři / scholii. ${ }^{94}$ Zdá se tedy, že ačkoliv pomůcky k řecké výuce / četbě na Ambrasu nescházely, při četbě byla spíše vyžadována opora v latině, což se potvrzuje i v Harantově cestopisu.

Není bez zajímavosti si všimnout, že velká část v cestopisu citovaných řecky pišíících autorů byla zastoupena i ve Ferdinandově knihovně. Z Harantova seznamu nebyli v rekonstruovaném katalogu nalezeni pouze byzantští autoři Sózomenos, Sókratés a Euagrios Scholastikos, Láoníkos Chalkokondylás, Níkéforos Grégorás, Níkéforos Bryennios a Anna Komnéna (díla obou nejspíš nebyla použita ani Harantem), Basileios I. (tj. Ke-

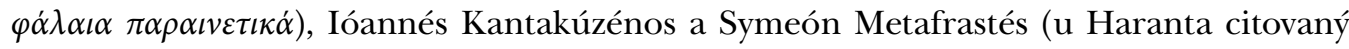
zprostředkovaně), Synopsis Basilicorum, ze starověkých Filémón, Dífilos (u Haranta cito-

89 V letech 1593-1597 se účastnil bojů s Turky v Uhrách, r. 1601 byl oficiálně jmenován číšníkem a komorníkem císaře Rudolfa II., r. 1607 dvorním radou. Viz Harantův životopis Koldinská (2004).

90 Purš \& Kuchařová I (2015: s. 290-291, 351).

91 Purš \& Kuchařová I (2015) - komentář, Purš \& Kuchařová II (2015) - katalog.

92 Podrobněji viz Purš \& Kuchařová I (2015: s. 351-352).

93 1Theo 196 („Testamentum novum Graece“), 4Va 659 („Suida Graecus“), 4Va 660 („Vita Plutarchi Graece“), 4Va 759 („Appianus Alexandrinus Graecus“), 5Co 235 („Opera Apollonii Rhodii graece“), 4Va 520 („Historiae Romanorum imperatorum carmine graeco redditae, a Zacharia Ortho, poetae/!/ laureato"). 
vaný zprostředkovaně) a Menandros, Theofrastos z Eresu, Níkandros z Kolofónu, Dionýsios Periégétés, Héródiános, Hérakleidés Lembos a Diktys z Knóssu.

\section{Řecká slova a řecké texty $v$ cestopisu}

Řecká slova zapsaná alfabetou a řecké úryvky se v cestopisu vyskytují ve velmi malé míre. Jak bylo poznamenáno výše a jak je patrné z uvedených příkladů odkazů z cestopisu, názvy děl a jména autorů (včetně jejich zkratek) jsou uváděna v latinizované podobě

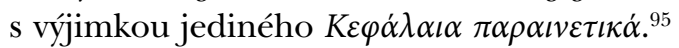

Pokud Harant uvádí z řecky psaných děl citáty, jsou v naprosté většině v latině. ${ }^{96}$ Výjimky tvoří české parafráze Aristotela ${ }^{97}$ Apollónidova epigramu o orlu a lučištníkovi, ${ }^{98}$ Aischina ${ }^{99}$ a Přehledných dějin Geórgia Kedréna, ${ }^{100}$ což však četbu řeckého originálu jednoznačně nedokazuje.

Kromě toho najdeme v cestopisu dva Harantem nelokalizované latinské citáty pocházející z řeckých autorů, které svědčí pro využíání překladů či bilingvních vydání, anebo spíše sbírek citátů: nepřesně přeložené přísloví o Krétanech ze Strabónova Zeměpisu (podle Haranta „staré latinské př́slovi“) ${ }^{101}$ a rčení o starověké Alexandreii uvedené v Athénaiových Hodujicich sofistech. ${ }^{102}$

95 Harant (2017: 2. d., s. 11).

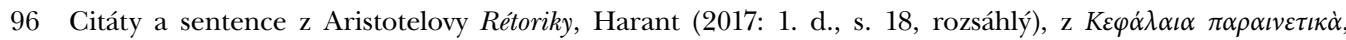
Harant (2017: 2. d., s. 11, rozsáhlý), Démosthenova prooimia č. 16, Harant (2017: 2. d., s. 8), a 3. řeči olynthské, Harant (2017: 2. d., s. 9), Platóna, Harant (2017: 2. d., s. 9), Menandra, Harant (2017: 2. d., s. 9, 121), Řehoře Nazianského, Harant (2017: 2. d., s. 10), Ísokrata, Harant (2017: 2. d., s. 10), Filémóna, Harant (2017: 2. d., s. 10), Lúkiána, Harant (2017: 2. d., s. 10), Dífila, Harant (2017: 2. d., s. 30), Antifilova epigramu, Harant (2017: 2. d., s. 262).

97 Harant (2017: 1. d., s. 17): „Aristoteles, znamenitý filozof, svědčí, že známost cizích a domácích věcí nejpodstatnější v životu obcování užitek přináší. " U Aristotela nedohledáno, ale vzhledem k takto obecnému odkazu jde nejspíš o tvrzení převzaté z neuvedeného (soudobého) díla; o něco dál navíc Harant odkazuje na Rhétoriku 1360aBekker, z níž obšírně latinsky cituje také o významu cestování: „Aristoteles lib. 1. rhet. cap. 7. píše: Itaque perspicuum est ad legum ferendarum scientiam plurimum conducere terrarum peregrinationem, in qua multarum gentium instituta legesque licet cognoscere; at vero in consiliis publicis historiarum et antiquitatis cognitio mirifice utilis est. Totižto že pro nabytí umění, práv a ustanovení lidských vyměření nejvíce světa putování napomáhá, v tom množství národův obyčejové a správy poznati se mohou, obzvláštně pak v radách zemských historie a staré paměti známost velice potřebná jest."

98 Harant (2017: 1. d., s. 112): „Jakož toho příklad divný se čte, že jeden v Cretě orla v letu šípkou dostřelil a trefil, kterýž z vysoka prudce dolů spadši na hlavu střelce upadl a jeho týmž šípem na smrt zranil, takže tu oba umřeli. Apollonides in epigram. 1."

99 Harant (2017: 1. d., s. 317): „Aeschines, řečník slavný, propověděl, že tři věci člověka chvály hodného činí: totiž když kdo rád a s chutí do kostela chodí, na vojnu z potřeby, ale na hody ani dobrovolně, ani z přinucení

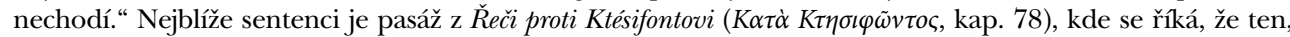
kdo si nevede spořádaně v soukromých záležitostech, nebude nikdy spolehlivý ani v záležitostech státních.

100 Harant (2017: 2. d., s. 7): „Cedrenus ačkoli krátce, však vlastně rozličné povahy škrybentův a kněh spisovatelův vypisuje těmito slovy: Kdo knihy píše, činí to (prý) anebo proto, že sobě commentarium, totiž pamět věcí rozličných shromažd’uje, aneb pro nějaký zvláštní užitek, aneb někomu $\mathrm{k}$ vůli, aneb pro to oboje, a naposledy bud'to z přinucení, aneb jiným na ubližení.“ (U Kedréna nenalezeno.)

101 Harant (2017: 1. d., s. 112): „O jejich povědomosti jest staré latinské přísloví: Cretensis mare nescit, 
Dále tentýž závěr podporují zmíněná česká parafráze Geórgia Kedréna, kde se objevuje latinské slovo commentarius ${ }^{103}$ a bibliografická citace knihy z Obecných dějin Efora z Kýmé,

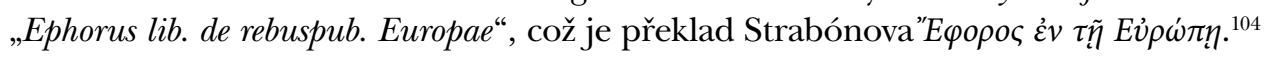

Jediným delším řeckým textem v cestopisu je přepis osvědčení z kláštera sv. Kateřiny na Sinaji, z nějž se na úroveň Harantovy řečtiny usuzovat nedá; není prosto chyb, avšak spíše typografických. ${ }^{105} \mathrm{~K}$ textu je připojen doslovný český překlad, nabízí se ovšem otázka, jestli nemohla být právě česká verze verzí prvotní, podle níž si náš poutník nechal vyhotovit řecké potvrzení. Podezřelé jsou třeba i dva latinismy, které se v potvrzení na-

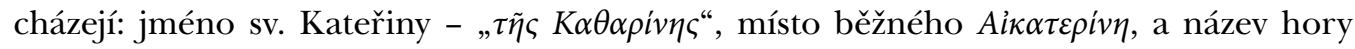

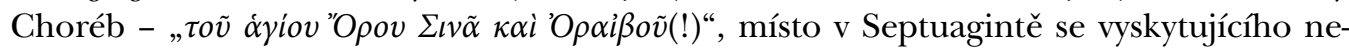
sklonného $X \omega \rho \eta \beta$ (ve Vulgatě Horeb). Toto jsou samozřejmě ale jen spekulace.

Dalšími případy řečtiny jsou dva citáty z Bible. Prvním je nápis na Ježíšově kříži, přepsaný vedle latiny řecky a dokonce hebrejsky, v obou posledních případech jen s drobnými grafickými nedostatky (hebrejština, uvedená na prvním místě, je zde z grafických důvodů vynechána): ${ }^{106}$

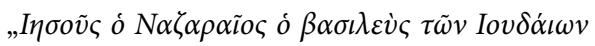 \\ IESUS NAZARENUS, REX IUDAEORUM“107}

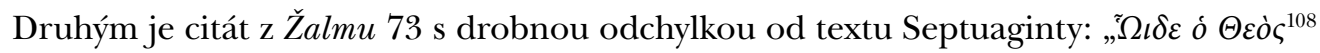

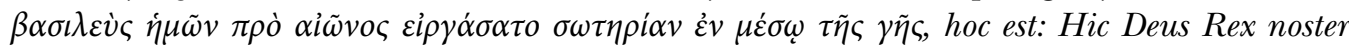
ante secula operatus est salutem in medio terrae “. ${ }^{109}$

Tyto biblické citáty, ale ani zmínka o textové variantě z řecké Septuaginty ${ }^{110}$ nejsou jednoznačným důkazem, že Harant používal samostatný řecký text Bible: biblický text v hebrejštině a řečtině spolu s textem latinským bylo možné najít např́íklad v polyglotních Biblích oblíbených v 16. a 17. století.

Kretenských moře nezná. Ale oni je znají, jako by možné nebylo z toho ostrovu rodilého najíti, který by se plavbě na moři rozuměti neměl.“; překlad předpokládá jako výchozí latinskou verzi (-is přeloženo jako ak.

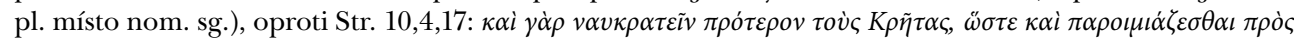

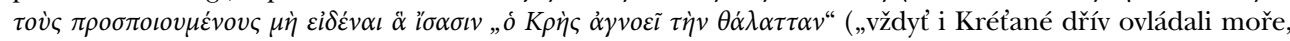
takže vzešlo př́ísloví o těch, kdo předstírají, že neumí to, co umí: ,Krétan nezná moře““).

102 Harant (2017: 2. d., s. 249): „A příčinou takového bohatství mezi příslovím tehdáž předek mělo ten, že ř́kávali: aurea Alexandria, Antiochia pulchra, Nicomedia speciosa, Alexandrie zlatá, Antiochie pěkná, Nikomedie krásná“. Ath. 1,36Kaibel.

103 Harant (2017: 2. d., s. 7).

104 Harant (2017: 1. d., s. 113), Str. 10,4,9.

105 Harant (2017: 2. d., s. 113-114) a komentář Harant (2017: 2. d., s. 506).

106 Harant (2017: 1. d., s. 192-193).

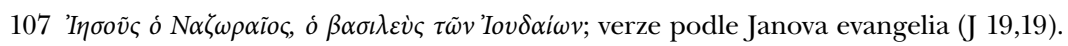

108 O $\delta \dot{\varepsilon} \Theta \varepsilon \dot{s} \varsigma$.

109 Harant (2017: 1. d., s. 194); Ž 74 podle Českého ekumenického překladu.

110 Harant (2017: 1. d., s. 304): „Abraham pod stany bydlel a tu anděly jdoucí, aby Gomoru a Sodomu vyvrátili, $\mathrm{k}$ sobě na nocleh přijal, jim pod velikým dubem, jakž jej 70 vykladačů jmenují, aneb terebinthem, jakž Iosephus píse, nohy myl“. 
Kratší řecké úryvky představují dva citáty př́ísloví ze slovníku Súda, z nichž však ani jedno uvedení nedokazuje, že Harant se Súdou přímo pracoval. První se týká Syřanů, Harant je volně interpretuje a doplňuje odpovídajícími italskými příslovími: ${ }^{11}$

„Ale tento národ z většího dílu jest velmi lenivý, zahálčivý a chudý, nevěrný, lehkomys-

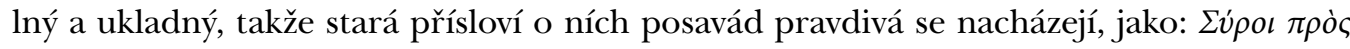
Фoivı $\alpha \varsigma(!)$, vlasky jako by řekl: A un tristo ge(!) ne vol uno e mezzo, ${ }^{112}$ totiž: Syrové proti Fenickým; jako by řekl: Syrus v šibalství mistrem Fenického jest, aneb vlasky: Maestro sopra i maestri, mistr nad mistry. Suidas, Caelius lib. 18. c. 24."

V Súdě se sice dané př́sloví nachází, ${ }^{113}$ nicméně jej i s odkazem na Súdu jako na původní zdroj uvádí také Harantem dále citovaná encyklopedická kompilace ze starověkých autorů italského humanisty Ludovica Caelia Rhodigina (Lodovico Ricchieri, 1469-1525) Lectionum antiquarum libri $\mathrm{XXX} .{ }^{114}$ Uvedení sekundárního i primárního odkazu vedle sebe je pro Haranta typické, ${ }^{115}$ domnívám se proto, že i zde pracoval s Caeliovým dílem, které na několika málo stranách 1. dílu cestopisu cituje celkem třikrát, vždy s přesností na knihu a kapitolu. ${ }^{116}$

Druhé přísloví má dokládat obecně známé špatné vlastnosti Krétanů, zdroj není Harantem uveden: ${ }^{117}$

„Srovnávají se také i jiná, před sv. Pavlem mezi lidi vzešlá adagia, totižto přrísloví, o Cretenských, jako: Cretenses mendaces, Cretenští lháři, Cretizat cum Cretensi, Cretensis cum Cretensi, o těch řečeno, kteříz lež podobně Cretenským mluvili, aneb že lhář lháře oklamal. Item

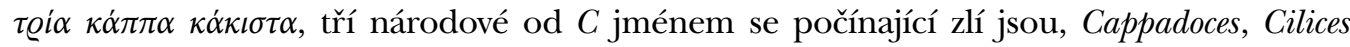
a Cretenses."

Přísloví najdeme jednak u Kónstantína Porfyrogennéta, ${ }^{118}$ jehož ale Harant nikde v cestopisu nezmiňuje, jednak ve slovníku Súda. ${ }^{119}$ Avšak vzhledem k výše zmíněnému případu i k tomu, že tu neuvádí žádný zdroj, se jeví pravděpodobnější, že čerpal z nějaké raně novověké sbírky adagií.

111 Harant (2017: 1. d., s. 432).

112 A un tristo ce ne vuol uno e mezzo, „na jednoho bídáka je třeba jeden a půlkrát takového.“

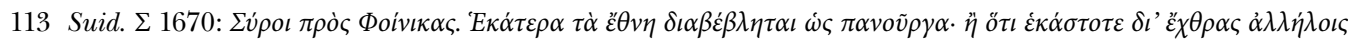

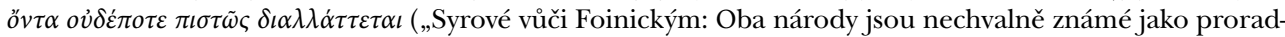
né; nebo protože se kvůli vzájemnému nepřátelství nemohou opravdově usmířit.“ Překlad Jana Steklá).

114 Kn. 18, kap. 34 (nikoliv 24), s. 719a: Incessitur tamen Syrorum gens, ut mortalium avidissima, sicuti Hieronymus

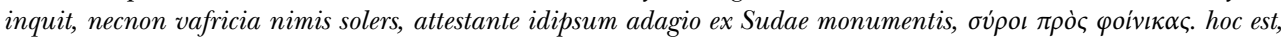
adversum Phoenices Syri... („A přece je národ Syřanů napadán jakožto ze smrtelníků nejchtivější, jak říká Jeroným, jakož i nadmíru prohnaný a lstivý, což dokládá právě přísloví z pramene Súdy, Syřané vůči Foiníčanům. To jest Foiníčané proti Syřanům...").

115 Viz Melounová (2017).

116 Harant (2017: 1. d., s. 424, 426, 432) a také Harant (2017: 2. d., s. 254).

117 Harant (2017: 1. d., s. 113).

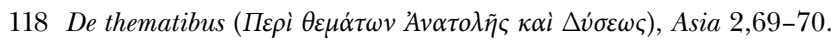

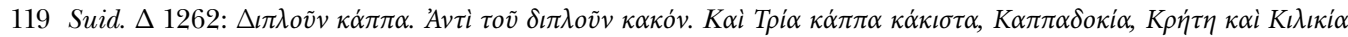
(„Dvojité kappa: tj. dvojité zlo. Také Tři nejhorší kappa: Kappadokie, Kréta a Kilikie“). 
Pak už se jedná jen o jednotlivá řecká slova. V řecké podobě je uveden název židovské

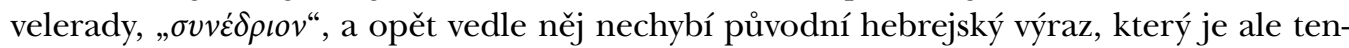
tokrát zapsaný latinkou. ${ }^{120}$

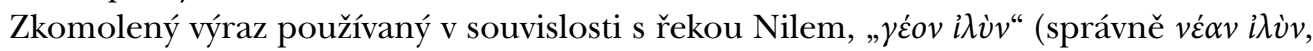
„[přinášející] nové bahno“) Harant, jak sám přiznává, převzal od vergiliovského komentátora Servia (kol. r. 400). ${ }^{121}$ Spojení véav ìv̀v se objevuje i v 9. knize Héliodórových Aithiopik, na niž Harant odkazuje o něco dříve také v souvislosti s Nilem; ${ }^{122}$ to, že zde uvádí Servia, který řecké spojení zakomponoval do svého latinského textu, je důkazem, že Harant nepracoval s řeckým vydáním Héliodóra ani s bilingvní verzí jeho díla.

Pro zajímavost uved'me, že v knihovně arcivévody Ferdinanda se nacházelo zřejmě řecké vydání slovníku Súda (4Va 659; „Suida Graecus“; viz výše) a dokonce i jedno vydání, které mělo zahrnovat Súdu s Héliodórem (4Va 760; „Suidas et Heliodorus compacti“).

Použití bilingvního řecko-latinského vydání lze odůvodněně předpokládat v případě Hérakleida Lemba, který vycházel v 16. století společně s Ailiánovými Rozmanitými př́-

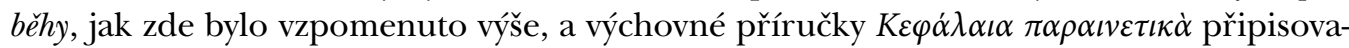
né císaři Basileiovi I., která je jediným případem, kdy Harant odkazuje na řecký název

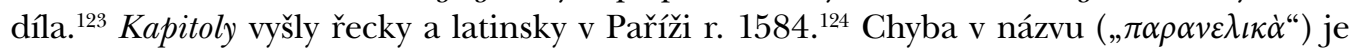
jednoznačně „překlepem“, v rejstříku autorit je název uveden správně. ${ }^{125}$

\section{Závěr}

Z cestopisu Kryštofa Haranta si sice nemůžeme udělat jasnou představu o autorových jazykových kompetencích v oblasti klasické a byzantské řečtiny, avšak na základě analýzy citací a citátů řecky psaných děl lze říci, že Harant při práci s řecky psanou literaturou preferoval latinské překlady nebo bilingvy, popř. sahal po soudobých sbírkách sentencí nebo jiných dílech kompilačního rázu. Latinské překlady v jeho době existovaly ke všem dílům, která asi reálně použil, je jen otázkou, co a v jaké podobě měl k dispozici, když sepisoval cestopis, což se bohužel vzhledem k absenci úplného inventáře jeho knihovního majetku už nedá zjistit. Není rozhodně na místě zcela vyvracet tvrzení Marie Koldinské, že Harant nabyl na Ambrasu kromě jiných jazykových znalostí i znalost řečtiny, v arcivévodském knihovním fondu materiály k výuce řečtiny a řecké četbě nechyběly. Je však tře-

120 Harant (2017: 1. d., s. 233): „Takže se souditi jináče nemůže, než že na tom místě stál rathauz židovský,

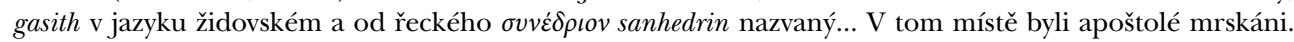
Act. 5."

121 „Ennius ji nazývá Melon, Servius yéov ì $v$ (!), že černou a novou zemí zakaluje Egypt“. Harant (2017: 2. d., s. 226). Jde o Serviův komentář ke Zpěvưm rolnickým 4,291; odkaz na Ennia je převzat ze Serviova komentáře k Aeneidě 1,741 .

122 Hld. 9,22,5; Harant (2017: 2. d., s. 221).

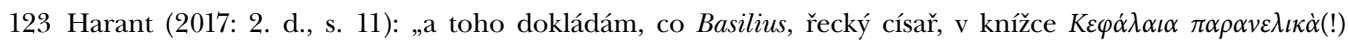
o užitcích historií synu svému předkládá“.

124 Titul tisku: „BA $\Sigma \mathrm{I} \Lambda$ EIOY TOY P $\Omega M A I \Omega N$ BA $\Sigma \mathrm{I} \Lambda \mathrm{E} \Omega \Sigma$ KEФA $\Lambda$ AIA $\pi \alpha \rho \alpha \iota v \varepsilon \tau \iota \kappa \dot{\alpha} . .$. BASILII ROMANORUM IMP. Exhortationum capita..."

125 Harant (2017: 2. d., s. 371); ač s jiným „překlepem“: „Basilius Caes. $\kappa \varepsilon \varphi \dot{\alpha} \lambda \alpha$ (!) $\pi \alpha \rho \alpha \iota v \varepsilon \tau \iota \kappa \dot{\alpha} “$. 
ba dodat, že důkazy pro Harantovo řecké vzdělání jsou pouze nepřímé a ani na základě cestopisu nelze obecně určit, jaké pokročilosti v řečtině Harant dosáhl a kdy k tomu došlo (na Ambrasu? samostudiem?). Cestopis každopádně vybavil odkazy na širokou škálu řecky píšících autorů starověkých i byzantských a přítomností několika řeckých úryvků a slov, jež zakomponoval do vlastního textu, dokázal, že byl schopný minimálně základní orientace $\mathrm{v}$ řeckém textu.

\section{Bibliografie}

Aelianus, C. (1553). Aeliani De varia historia libri XIIII nunc primum $\mathcal{E}$ Latinitate donati $\mathcal{E}$ in lucem editi Iusto Vulteio Wetterano interprete: Item De politiis sive Rerumpublicarum descriptiones ex Heraclide eodem interprete. Lugdunum: Ioan. Tornaesius et Guil. Gazeius.

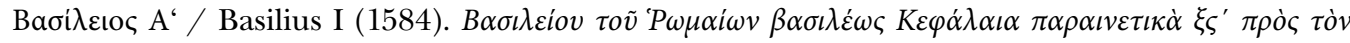

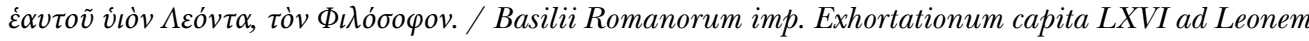
filium, cognomento Philosophum. Lutetia: Federicus Morellus.

Beroaldus, M. (1575). Matth. Beroaldi Chronicum scripturae Sacrae autoritate constitutum. [Geneva:] Antonius Chuppinus.

Bibliander, Th. (Ed.). (1550). Machumetis Saracenorum principis, eiusque successorum vitae, doctrina, ac ipse Alcoran. [Basilea].

Binns, J. W. (1978). Latin Translations from Greek in the English Renaissance. Humanistica Lovaniensia: Journal of Neo-Latin Studies, 27, 128-159.

Botley, P. (2004). Latin Translation in the Renaissance: The Theory and Practice of Leonardo Bruni, Giannozzo Manetti and Desiderius Erasmus. Cambridge: Cambridge University Press.

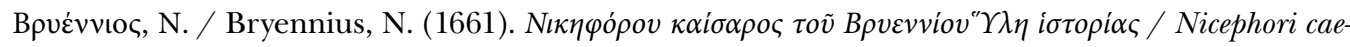
saris Bryennii Commentarii de rebus Byzantinis: Prodeunt nunc primum opera E studio Petri Possini e Soc. Iesu. Parisii: Typographia regia.

Burke, B. (1999). Purple and Aegean Textile Trade in the Early Second Millenium B. C. In P. Betancourt \& V. Karageorgis et al. (Eds.), Meletemata: Studies in Aegean Archaeology Presented to Malcolm H. Wiener as He Enters his 65th Year: Aegeum 20 (pp. 75-82). Liège: Université de Liège.

Caelius, L. R. (1566). Lodovici Caelii Rhodigini Lectionum antiquarum libri XXX recogniti ab auctore atque ita locupletati, ut tertia plus parte auctiores sint redditi. Basilea: Ambrosius et Aurelius Frobenii fratres.

Comnena, A. (1610). Alexiados libri VIII ab Anna Comnena de rebus a patre gestis scripti: Nunc primum a Davide Hoeschelio A. ex Aug. Reip. bibliotheca editi. Augusta Vindelicorum: ad insigne pinus.

Damascenus, I. (1546). Sancti Patris Ioannis Damasceni... universa, quae obtineri hac vice potuerunt, opera, summo Henrici Gravii studio... eruta. Colonia: Officina Petri Quentel.

Eusebius Caesariensis et al. (1570). Historiae ecclesiasticae scriptores Graeci: Ioanne Cristophorsono Anglo Cicestrensi quondam episcopo interprete. Colonia Agrippina: haeredes Arnoldi Birckmanni.

Harant z Polžic a Bezdružic, K., Bočková, H. \& Melounová, M. (2017). Putováni aneb Cesta z královstvi českého do města Benátek, odtud po moři do země Svaté, země jůdské a dále do Egypta a velikého města Kairu (Vol. I-II). Praha - Brno: Nadační fond Česká knižnice; Ústav pro českou literaturu AV ČR; Host. 
Kazhdan, A. P. et al. (1991). The Oxford Dictionary of Byzantium (Vol. 1-3). New York - Oxford: Oxford University Press.

Koldinská, M. (2004). Kryštof Harant z Polžic a Bezdružic: Cesta intelektuála k popravišti. Praha: Paseka.

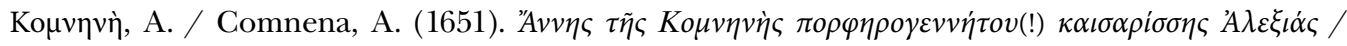
Annae Comnenae Porphyrogenitae Caesarissae Alexias sive de rebus ab Alexio imperatore vel ejus tempore gestis libri quindecim: E bibliotheca Barberina nunc primum editi et a Petro Possino ... Latina interpretatione ... illustrati. Parisii: Typographia regia.

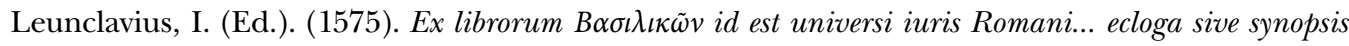
hactenus desiderata, nunc edita per Ioan. Leunclaium. Basilea: Eusebius Episcopius \& Nicolai Fr. heredes.

Melounová, M. (2017). Debtors and Decoctores in the Travelogue of Christopher Harant of Polžice and Bezdružice: Some Examples of How a Humanist Scholar Worked with Primary and Secondary Sources. Acta Universitatis Carolinae Philologica, 2, 283-292.

Mercator, G. \& Beroaldus, M. (1577). Chronologia, hoc est supputatio temporum ab initio mundi... Gerhardo Mercatore E Matthaeo Beroaldo authoribus. Basilea: Thomas Guarinus.

Migne, J.-P. (Ed.). (1845). Patrologiae cursus completus: Series Latina (Tomus XXV). Lutetia Parisiorum: apud editorem.

Migne, J.-P. (Ed.). (1857). Patrologiae cursus completus: Series Graeca (Tomus XXXV). Lutetia Parisiorum: apud editorem.

$O D B$ - viz Kazhdan.

Purš, I. \& Kuchařová, H. (Eds.). (2015). Knihovna arcivévody Ferdinanda II. Tyrolského: Texty. Praha: Artefactum. (I)

Purš, I. \& Kuchařová, H. (Eds.). (2015). Knihovna arcivévody Ferdinanda II. Tyrolského: Katalog. Praha: Artefactum. (II)

Volaterranus, R. (1603). Raphaelis Volaterrani Commentariorum urbanorum libri octo et triginta, accuratius quam antehac excusi. Hanovia: Claudius Marnius \& haeredes Ioannis Aubrii.

Mgr. et Mgr. Markéta Melounová, Ph.D. / marmel@mail.muni.cz

Department of Classical Studies

Masaryk University, Faculty of Arts

Arna Nováka 1, 60200 Brno, Czech Republic 